\title{
Women's perception of labor and birth care: obstacles to humanization
}

\author{
Percepção de mulheres na assistência ao parto e nascimento: obstáculos para a humanização
}

Percepción de las mujeres en el trabajo de parto y el cuidado del parto: obstáculos para la humanización

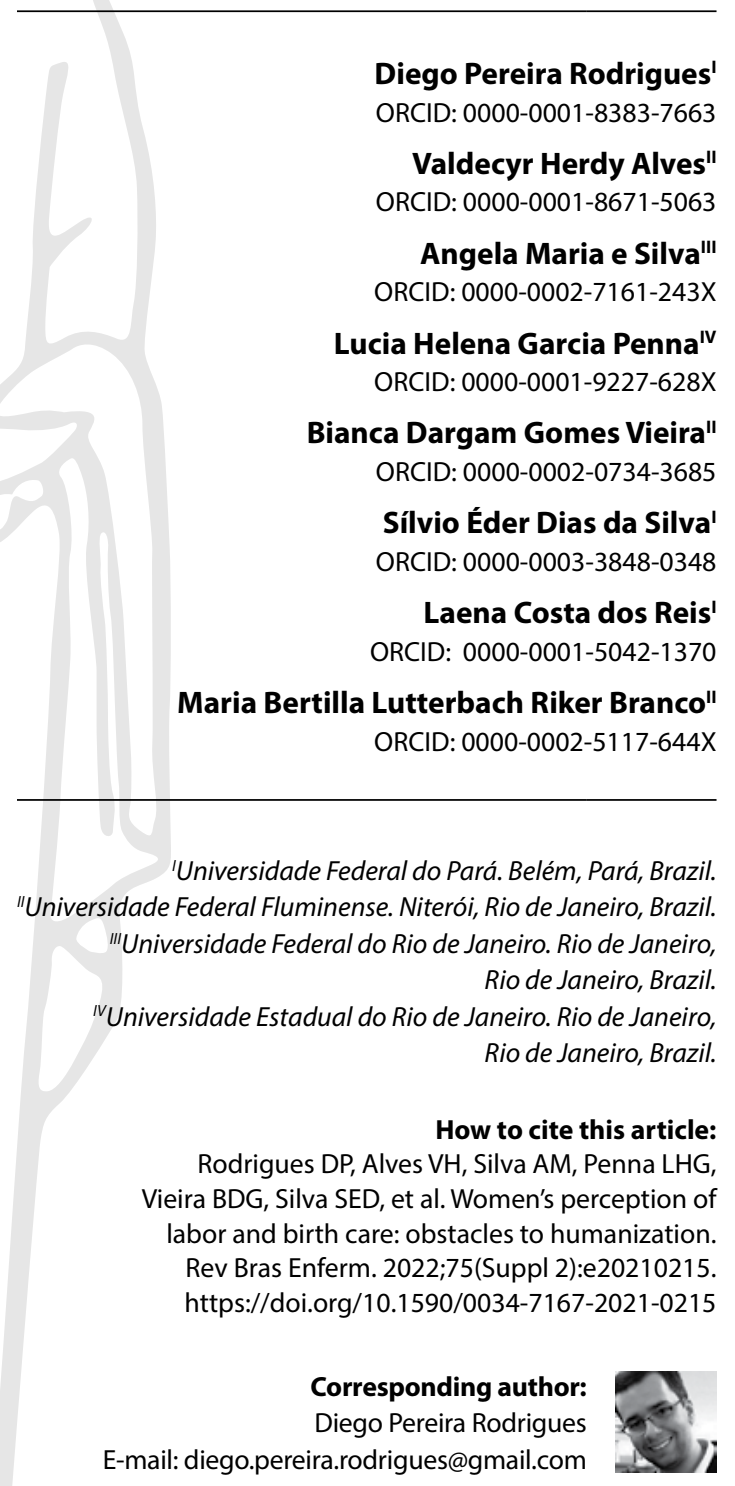

EDITOR IN CHIEF: Antonio José de Almeida Filho ASSOCIATE EDITOR: Alexandre Balsanelli

\begin{abstract}
Objectives: to understand women's perception regarding the care received during labor and birth. Methods: this is a descriptive-exploratory, qualitative study carried out with 54 postpartum women from hospitals in the Metropolitan Region Il of the state of Rio de Janeiro, from January to December 2018, using semi-structured interviews submitted to content analysis. Results: puerperal women's perceptions about the childbirth care they received indicated the use of interventions, such as pressure maneuvers on the uterine fundus during the expulsion period - Kristeller maneuver, episiotomy and repeated vaginal examination and without consent. The use of institutional routines, such as zero diet, horizontal birth and disrespect. Final Considerations: despite the encouragement of public humanization policies, the technocratic model is still present in obstetric care during childbirth. The humanization of obstetric care requires changes in attitudes and care paradigms, in order to guarantee respect and the right to quality care.

Descriptors: Nursing; Women; Parturition; Humanization of Assistance; Reproductive Rights.
\end{abstract}

\section{RESUMO}

Objetivos: compreender a percepção das mulheres quanto à assistência recebida durante o parto e nascimento. Métodos: estudo descritivo-exploratório, qualitativo, realizado com 54 puérperas de hospitais da Região Metropolitana Il do estado do Rio de Janeiro, de janeiro a dezembro de 2018, utilizando entrevistas semiestruturadas submetidas à análise de conteúdo. Resultados: as percepções das puérperas sobre a assistência ao parto recebida apontaram a utilização de intervenções, tais como manobras de pressão sobre o fundo uterino no período expulsivo - manobra de Kristeller, episiotomia e toque vaginal repetidos e sem consentimento. A utilização de rotinas institucionais, como a dieta zero, parto horizontal e desrespeito. Considerações Finais: apesar do incentivo das políticas públicas de humanização, o modelo tecnocrático ainda se faz presente na assistência obstétrica ao parto. A humanização da assistência obstétrica requer mudanças de atitudes e paradigmas assistenciais, a fim de garantir respeito e direito à assistência de qualidade.

Descritores: Enfermagem; Mulheres; Parto; Humanização da Assistência; Direitos Sexuais e Reprodutivos.

\section{RESUMEN}

Objetivos: comprender la percepción de las mujeres sobre la asistencia recibida durante el trabajo de parto y el parto. Métodos: estudio descriptivo-exploratorio, cualitativo, realizado con 54 puérperas de hospitales de la II Región Metropolitana del estado de Río de Janeiro, de enero a diciembre de 2018, mediante entrevistas semiestructuradas sometidas a análisis de contenido. Resultados: las percepciones de las puérperas sobre la atención recibida del parto indicaron el uso de intervenciones, como maniobras de presión sobre el fondo uterino en el período expulsivo - maniobra de Kristeller, episiotomía y toque vaginal repetido y sin consentimiento. El uso de rutinas institucionales, como dieta cero, parto horizontal y falta de respeto. Consideraciones Finales: a pesar del impulso de las políticas públicas de humanización, el modelo tecnocrático sigue presente en la atención obstétrica durante el parto. La humanización de la atención obstétrica requiere cambios de actitudes y paradigmas de atención, a fin de garantizar el respeto y el derecho a una atención de calidad. Descriptores: Enfermería; Mujeres; Parto; Humanización de la Atención; Derechos Sexuales y Reproductivos. 


\section{INTRODUCTION}

Childbirth safety is currently one of the milestones of current obstetric care and one of the emerging topics in the international health scenario, beyond women's expectations, a care that affects their health without harm and with better outcomes in the care provided at work of childbirth and birth ${ }^{(1)}$. It becomes necessary, in addition to timely access to health services ${ }^{(1)}$, a practice based on scientific evidence and without the use of outdated behaviors that are still employed in the context of care, being contradicted by guidelines and recommendations of international entities and the World Health Organization (WHO), which contributes to a transformation of obstetric care as a redefinition of behaviors adopted by health professionals ${ }^{(2-3)}$.

In this sense, the study presents women's perceptions in relation to the care offered during labor and birth in public maternity hospitals. The care to the parturition process constitutes a challenge for the safety of childbirth and birth care, being a practice still supported by attitudes disconnected with scientific advance, which are perpetuated by the work of health professionals, with institutional routines of health units ${ }^{(4-5)}$. The power and authority resulting from the institutionalization process of hospital routines, horizontal, protocol and instituted care support the various forms of knowledge and practices considered outdated, which constitute a risk to perinatal health ${ }^{(5)}$.

Currently, numerous changes have been discussed internationally in the scientific community, such as the universal use of continuous support from health professionals, which has shown positive effects with a reduction in unnecessary interventions, ensuring better maternal and neonatal outcomes. Continuous support ensures benefits such as reduced need for epidurals, reduced use of oxytocin, instrumental deliveries, cesarean deliveries, postpartum depression and neonatal admissions to specialized units. Thus, the international literature guarantees the shortening of labor duration, as well as better maternal satisfaction, bonding with the baby, better neonatal outcomes and reduced women's anxiety ${ }^{(6-7)}$.

But this support is still little used during obstetric care, as the predominance of care is linked to a high rate of hospital interventions, such as cesarean section, episiotomy, Kristeller maneuver, unnecessary vaginal examination, endogenous oxytocite, obstetric forceps, among others ${ }^{(3,6,8-14)}$. This fact is constituted by advancement of technology and use of a technocratic model in modern obstetrics, thus contributing to care aimed at intervention of the female body ${ }^{(6)}$.

In this way, the norms and routines are supported by the biological logic and anchored in the legal guarantee of their professional exercise of each individual on the female body, but what we see is the non-recognition of scientific value ${ }^{(9)}$, since the practice of qualified, safe and respectful care has its use value based on the best scientific evidence, in addition to guaranteeing respect for women.

In this scenario, in 2011, the federal government instituted the Stork Network (Rede Cegonha) in the Unified Health System (SUS - Sistema Único de Saúde) through Ordinance 1459 of June 24. The Stork Network has been identified as one of the most important inducing strategies in the qualification and safety process for the reproductive process, with a focus on maternal and child health around the organization of services and the safety of $\operatorname{car}^{(8)}$. The operationalization of the Stork Network promoted a movement in favor of humanization, with the rescue of women's role as subjects of the right to a qualified and safe birth.

WHO advocates that all women are entitled to the highest attainable standard of health, including the right to dignified and respectful care throughout pregnancy and childbirth ${ }^{(3,5,9-13,15)}$. Thus, the humanization of childbirth care processes enables the opening of dialogues in the field of knowledge and health practices in the ways established in health work established in/with the process of co-responsibility for the transformation of the reality of work itself, with the use of best practices, such as offering solid and liquid food, avoiding unnecessary interventions in the woman's body, respecting her privacy and autonomy, promoting care based on non-pharmacological pain relief technologies. This set of factors evidences the close relationship between senses, motivation, satisfaction and value perception that configure the aspects of live work in health ${ }^{(15)}$.

However, it is still necessary to implement changes in line with these important initiatives, as obstetric care presents some obstacles to the use of these practices, such as the lack of: professional training, institutional policy; maternity hospital infrastructure, knowledge of women and caregivers about their reproductive rights; attitude of reframing by professionals, in view of their performance and the care model. Moreover, there is an asymmetric relationship between health professionals and women, causing a crisis of confidence $\mathrm{e}^{(1,6-7,10-12)}$.

Thus, the study had as a guiding question: how do women perceive the practices used in the daily life of obstetric care? Thus, the study intends to create opportunities for humanization as a strategy for changes in care, with the redefinition of practices in daily life of childbirth and birth, the valuing of respectful care, safety, inhibiting any damage to perinatal health and the use of unnecessary interventions.

\section{OBJECTIVES}

To understand women's perception regarding the care received during labor and birth.

\section{METHODS}

\section{Ethical aspects}

The study was approved by the Institutional Review Board of the Universidade Federal Fluminense, as provided for in the Brazilian National Health Board (CNS - Conselho Nacional de Saúde) Resolution 466/2012. To preserve the respective secrecy, anonymity and reliability, the interviewees were identified with the letter $(P)$ for postpartum woman, followed by a numerical figure corresponding to the sequence of the interviews (P1, P2, P3, ..., P56), in addition to the guarantee of voluntary participation by signing the Informed Consent Form (ICF).

\section{Study design}

It is descriptive, exploratory and qualitative research. Descriptive research is established in the description of the characteristics of 
a given population or phenomenon, while exploratory research aims to bring researchers closer to the topic, in order to make them more accustomed to the facts and phenomena related to the research problem ${ }^{(16)}$. The Consolidated Criteria for Reporting Qualitative Research (COREQ) ${ }^{(17)}$ was used to help researchers to report qualitative research information with transparency and quality.

\section{Study setting}

The research had as settings the rooming-in of public maternity hospitals in the maternal and child health care network in Metropolitan Region II of the state of Rio de Janeiro, Brazil, namely: Hospital Universitário Antônio Pedro, Hospital Estadual Azevedo Lima, Maternidade Municipal Dr. ${ }^{a}$ Alzira Reis Vieira, Maternidade MunicipalDr. Mario Niajar. These units correspond to woman care at habitual risk and high risk in labor and birth care linked to SUS in Niterói and São Gonçalo.

Metropolitan Region II of Rio de Janeiro has a territorial extension of $2,711 \mathrm{~km}^{2}$, corresponding to $6.18 \%$ of the state territory, integrating seven municipalities, such as Niterói, São Gonçalo, Maricá, Itaboraí, Tanguá, Rio Bonito and Silva Jardim, having an absolute occupancy of 1,940,536 inhabitants. The region in relation to women's access to maternity hospitals includes a university hospital, a state hospital, both for medium and high-risk obstetric care, four municipal units for usual-risk obstetric care and a philanthropic unit for usual-risk.

\section{Data source}

The research participants were 56 postpartum women, 14 from each health unit, who met the following inclusion criteria: women in immediate postpartum period; over 18 years of age; who had vaginal births in public maternity hospitals; with a stay of 12 hours or more in the unit. The exclusion criteria took into account women who presented any physiological change or instability, such as postpartum hemorrhage and hypertensive syndrome, and psychological syndromes, such as depression or anxiety crises, that would make their participation unfeasible.

Knowledge of childbirth type and information about puerperal women's health status were verified in nursing records and from information provided by professionals in the sector.

An initial reception was carried out in each scenario in the puerperium wards with women, in order to establish a more empathetic and communicative relationship, in order to present the research objectives and the way to conduct the data collection technique. At this point, a collaborative relationship was established with participants, demonstrating the importance of their reports regarding the care provided during labor and birth. Thus, their testimonies would be essential to respond to the objectives of the study and identify obstetric care in these maternities.

After this welcoming and communicative establishment process, the sample was delimited by convenience, in which participants were approached, in person, by the main researcher, inviting them to participate in the research. It is noteworthy that none of the approached participants refused to participate in the study. The quantitative of the study sample was established by theoretical saturation $^{(18)}$, when new themes or types of utterances are not consistently added after new interviews.

It is noteworthy that none of the participants knew about the interviewer's personal objectives and characteristics, as well as no relational movement with the institutions to carry out the study. Thus, the recruitment of women in each scenario had no way of approaching the researcher, i.e., a direct relationship (prior contact) with women, because this entire descriptive process of the reception and recruitment stage was carried out at the time of data collection.

\section{Data collection and organization}

The investigation route used the semi-structured interview, with closed-and open-ended questions related to the social and economic identification profile of women, and the completion of the following research questions: how was your experience of the care process in childbirth and birth? What is your perception of this implemented care? Data were collected, individually and privately, only with the mother and the researcher, between January and December 2018 in a reserved room in the maternity hospitals. During the interview, the newborn was under the companion's care in the rooming-in of each unit.

Thus, the interviews were conducted, in depth, in a single moment with the participant, with an average duration of 45 minutes each, which enabled the investigation of the perception of obstetric care received by health professionals. The testimonies were recorded on a digital device, with prior authorization from participants, and later transcribed in full to follow the process of processing the material.

The data collection technique was conducted only by the main researcher, avoiding a differentiated conduct, given the way that each researcher could introduce in the interview, while the research team was in charge of acting in data treatment and analysis. It is noteworthy that the researcher, at the time, held a master's credential, in which he had mastery of the interview technique, as he received all the training from the research team's PhD members, as well as experiences of applying the interview in other studies.

It is noteworthy that both the main researcher and the team of researchers had no personal and professional relationship with the institutions, avoiding any conflict of interest in the study. The interest was only related to the problem of the study, not because of the interests of the institutions and interviewees in the study.

\section{Data analysis}

In data analysis, we sought treatment based on content analysis ${ }^{(19)}$, with the objective of discovering the content of the manifested speech, which presupposes in three moments: 1) preanalysis of statements (material organization, with text skimming, with a choice of documents to be analyzed, a priori, or selecting those that were collected, a posteriori, construction of the corpus based on exhaustiveness, representativeness, homogeneity and relevance, formulations of hypotheses or objectives and material preparation); 2) material exploration and treatment of results 
(coding and categorization of material - codification involves the cut made of the units of meaning, which can be words, the theme, the object or referring to the event, and to select the units, it must take into account the relevance, being able to obtain frequency or occurrence, called contingency analysis; categorization will follow semantic, syntactic, lexical, or expressive criteria); 3) inference and interpretation (interpretation of the results obtained, based on inference, constituting a type of controlled interpretation that can be supported by the constitutive elements of the classical communication mechanism through the message - meaning and code and by the sender and the receiver) ${ }^{(19)}$.

The study obtained the descriptive report of the testimonies of the care received and women's perception regarding obstetric care, with obstetric care as the analytical category of the study. In this sense, the team of researchers carried out treatment of results and analysis of the material, guided by the analysis framework ${ }^{(19)}$.

Thus, the data were sorted, with the transcript of the interviews in full. A text skimming and grouping was performed, submitting to a detailed and exhaustive analysis and confronting with the scientific literature. Following the plan, the selection of units of analysis (units of meaning) was carried out, appearing, through their frequency (repetition of meanings), namely: disrespect (F45\%), obstetric interventions (F-62\%), routines institutional ( $F-$ $56 \%$ ), abandonment, non-welcoming ( $F-36 \%)$, negligence ( $F-32 \%)$, lack of freedom and privacy (F-28\%), aggression and violence (F-25\%). Finally, in the last phase of the analytical process, the identification of the units of meaning allowed, in the last stage of analysis, the categorization of the constructive elements and the regrouping of meanings, based on non-aprioristic categorization.

\section{RESULTS}

Of the 56 women, there was a predominance of participants aged between twenty and five and thirty years (50\%), self-declared brown (50\%) and black (27.7\%) skin color, with Catholic religion (35.7\%), complete high school (64.2\%), in stable union (71.4\%), off the books (53.5\%), being housewives, that did not contribute to family income, which ranged from 3 to 4 minimum wages (35.7\%) - based on R\$954.00 (about US\$174), minimum wage in 2018, with own housing (50\%), with up to six family components (64.2\%).

Non-aprioristic categorization made possible from participants' responses, the construction of the following categories: 1) Obstetric interventions in childbirth and birth: a counterpoint to scientific evidence; 2) Humanization as a necessity in the daily routine of obstetric care in women's voices. It is mentioned that currently some obstetric practices introduced in the daily care of women and newborns have been questioned, for not bringing any benefit in its use, such as episiotomy without consent, excessive vaginal examination and use of endogenous oxytocin, maneuvers pressure on the uterine fundus in the expulsive period (Kristeller maneuver). These aspects were guided by scientific literature appropriation and based on the humanization policy and national guidelines on normal childbirth.

Obstetric interventions in childbirth and birth: a counterpoint to scientific evidence

Women's perceptions pointed out the experience of obstetric practices used in daily labor and childbirth. Among these practices,
Kristeller maneuver (described by German physician Samuel Kristeller), which consists of compression of the uterine fundus during the second period of labor aiming at its abbreviation, being considered inappropriate. Participants considered it a frightening and horrible moment through the use of obstetric care.

They climbed on me and pushed my belly, I was a little scared, because they didn't say anything. (P5)

They stood on top of me pushing my belly, it was this horrible part that I didn't like, they stood up my belly and kept pushing, they put the arm and pushed down, making me feel very bad at the time. The strength he was putting hurt my belly and I could not push anymore. (P15)

Some procedures performed were perceived as disrespectful interventions on your body, such as the use of episiotomy in the context of birth. Episiotomy, from participants' perception, was a moment of brutality, painful, without information and empathy, going against the recommendations of strategies for humanization:

Who stitched me was rude [...] when he stitched me was the worst part! I felt like an animal. (P1)

Ifelt horrible, treated like an animal [...] stitched me all over, he was rude at the time, it was horrible and still hurts a lot in the place; it was conducted without patience with me and he did not say anything to me just said after it was done, and before he didn't say anything that he stitched me. This situation was horrible and also I did not want it to happen. (P24)

Vaginal examination, performed in obstetric assessment, present in the daily practice of maternity hospitals, was also perceived as a disrespectful intervention, without dialogue and empathy in the care process, according to the following statement:

And when he examined me he did not say anything, he left the room, took a form and began to fill and I saw that it was hospitalization form; and when he finished filling, he called the nurse to take me and said "Let's walk", to go up the ramp, and he said I had eight dilation, I can't walk, let me run, then; he ran and brought me here to the pre-childbirth room and in that room I stayed; they examined me all the time, l asked to operate, he said he couldn't operate because he's going to take the baby out much sooner, let him come through normal birth. (P22)

\section{Humanization as a necessity in daily life of obstetric care in women's voice}

Abandonment was present in puerperal women's perceptions, constituting a direct relationship with the induction of labor for oxytocite administration. Participants felt abandoned by health professionals, with no relationship, empathy and care.

I felt abandoned! [...] they [professionals] only put the serum there, leave you alone and say nothing! [...] I started to feel more pain, pain, pain and I almost died, and no one would be there to see, because they tell you that they have to have $10 \mathrm{~cm}$ of dilation and leave you suffering, suffering, suffering and when you cannot take it anymore, they [professionals] come and help you. (P1) 
It was bad, we call, call, but they take a long time to pay attention to you, there are a lot of pregnant women and few nurses and you can't be there all the time, but it was bad, there could be more to pay attention, a strength, it would help. (P18)

The women perceived the lack of respect referring to feeling "thrown away" and "dumped", justified, in most cases, by institutional routines in obstetric care, such as the indication of the zero diet.

I felt dumped, because I had my son at dawn, I could not drink water or eat, I was painless [...] when the pain started, I stayed longer in the room and they brought nothing to me, because I could not drink or eat anything. We feel thrown away, like an animal! (P1)

We are starving [...] they did not give anything to eat and drink, we are starving [...] / felt weak in the prepartum room [...] about to faint [...] we feel a lot of pain [...] it was bad, because I was in pain, hunger, tired, I could not take it anymore [...] I thought I was going to faint! (P2)

They [professionals] told me that / could not eat, only after childbirth, and drink water too [...] I was very weak, really weak, and even more with the pain and contractions [...] / hardly had the strength to have my son [...] it was horrible this feeling. (P5)

Participants also highlighted their perceptions regarding the position for the time of childbirth/birth. They referred to the gynecological/lithotomy position as the most traditional modality in obstetrics in the way of being born, disregarding the freedom established by the humanization policies during childbirth:

Um, I was in the pre-childbirth room and they told me it's time, they took me to the room to have the baby and I had to lie down and put my legs up, and they [professionals] said to hold the iron to make contractions easier and faster, that's what happened. (P22)

When I left for the childbirth room, the nurse who was with me took me and put me in bed, lying down with my legs up [...] she asked to push and push and hold on to the iron for this [...] born fast and she was there to help out [...] and it was good and fast, because I got up and did what she said and right away the head came out and it was fast. (P30)

I found it uncomfortable, but I had to stay upright like him, he told me to stay, because I was crooked because I wanted to see the child leave and he scolded me, yelled at me to stay upright, I thought it was bad, and after he said stay straight in bed. (P42)

Verbal violence was present in obstetric care with the participants who, according to their perceptions, pointed to a verbal aggression, disrespecting the woman's uniqueness and her moment of giving birth, contributing with more pain during the period of childbirth and birth.

The health professional was there yelling at me; they have to help us and not scream [...] I was even more nervous and in pain [...] so I threw the serum on him. (P3)

It was very bad for me [...] it was my first birth treating me with rudeness, yelling at me [...] / did not like it at all [...] and they should have respected me better, this situation was complicated. (P4)
The professional at night complained and yelled at me to be quiet and shut up, he was screaming because of the pain, but my screams were bothering him [health professional] and he complained and did this, and I was quiet so I wouldn't have any problems because of him. (P37)

\section{DISCUSSION}

Obstetric care has been constantly modified over the years, with the incorporation of new knowledge, practices, conducts. These changes have been aligned with scientific evidence and the guidelines and recommendations of institutions, such as who, for care based on childbirth respect (humanized) and safety. It is noteworthy that unnecessary interventions have been obstacles to the safety and modification of the current model, with the incorporation of humanization, being the foundation for the transformation of obstetric practice in the country.

Kristeller maneuver, a non-recommended approach, which is an interventional practice in the context of childbirth and birth, performed by health professionals during the expulsion period with compression of the uterus fundus, aims to accelerate the expulsion period. On the other hand, this conduct performed is not a recommended practice by international and national organizations, such as the $\mathrm{WHO}$ and the $\mathrm{MoH}$, as its applicability produces a greater risk of maternal and fetal injuries ${ }^{(20)}$. In addition to this, this procedure is not recommended for its execution by professional entities, such as the Brazilian Federation of Gynecology and Obstetrics Associations (FEBRASGO - Federação Brasileira das Associações de Ginecologia e Obstetrícia), the Brazilian Association of Midwives and Obstetric Nurses (ABENFO - Associação Brasileira de Obstetrizes e Enfermeiros Obstetras) and the Federal Council of Nursing (COFEN - Conselho Federal de Enfermagem), entities of professionals who work directly in woman care in the obstetric field.

Scientific evidence shows that Kristeller maneuver should not be practiced. Although the results show that its applicability has a shorter duration in the second period of childbirth, there was an important increase in the risk of severe perineal lacerations, uterine rupture, dyspareunia and urinary incontinence six months after childbirth, in addition to neonatal complications such as shoulder dystocia, increased risk of a fifth minute Apgar score below seven, in addition to fetal sequelae such as hypoperfusion and cerebral palsy ${ }^{(21)}$. We need to expand discussions in the field of health work, focusing on job qualification, based on scientific evidence, expanding the reconfiguration of care during childbirth and childbirth described by health policies, especially humanization $^{(1-3,9,14)}$, inducing the childbirth care model transition in Brazil.

Thus, when a practice is based on health procedures already considered by scientific evidence as outdated, their maintenance becomes a disrespect for women's health. Ensuring women the best health behavior is a constitutional right and a duty of all health professionals. Lack of knowledge in the advancement of scientific value in health and the lack of continuing education favor a professional practice, often disconnected from current demands for safe care.

The purpose of obstetric interventions, in relation to the use of episiotomy, observed, in 11 studies of randomized clinical trials involving 5,977 women, the comparison of two groups of women, one group receiving selective episiotomy, and the other, 
episiotomy of routine. In this survey, it was found that women undergoing selective episiotomy had less severe perineal trauma. The rationale for performing this type of episiotomy was to prevent severe perineal trauma, which was not considered true given current evidence, because it was also identified that there was no benefit of routine episiotomy for women and their babies ${ }^{(22)}$.

Thus, the justification for performing episiotomy for preventing trauma and perineal lacerations is not proven ${ }^{(23-24)}$, and when we use this interventionist conduct in childbirth, it denies the scientific evidence that establishes the non-use of episiotomy as a routine practice in childbirth. It is evident that this care is supported by the lack of scientific knowledge, with institutional guarantee for health service management to maintain outdated routines; however, ensuring the best evidence favors the singular care centered on the woman rather than its applicability, which causes pain in women, as it is a "rude" intervention and without proper information and authorization, needing greater respect and empathy with women for their wishes on their bodies, as an alignment of conduct based on respect and humanization.

We must follow the same logic for excessive vaginal examination, as they must be performed every two hours, in the active phase of labor, with no need to repeat them in the passive phase. The WHO establishes that vaginal examination should be used every four hours, when the progression stop is assessed, being enough the time established by the international institutions of obstetrics ${ }^{(3,20)}$. Therefore, vaginal examination is not recommended before two hours and after four hours after the previous exam ${ }^{(20)}$ and, when performed excessively, it configures a disrespect and violation of the female body.

In this conception, a woman's body must be respected and excessive invasion must be avoided. The work for the obstetric condition assessment should, with respect to the woman, following the recommendations of international organizations that support a care with respect to physiology, inhibit unnecessary interventions ${ }^{(1-3,20)}$. Alternatives for assessing the active phase of childbirth should be proposed, such as the purple line as an effective option for assessing cervical dilatation and fetal descent, which has proven to be efficient; however, little used in practice, especially in Brazil, requiring further studies of its assessment to identify its evidence ${ }^{(3)}$.

However, for a change in this reality to occur, it is necessary that managers and health professionals make use of important strategies for a reorganization of care management in health services, of $\mathrm{MoH}$ initiatives, such as the Improvement and Innovation in Care and Teaching in Obstetrics and Neonatology project (APICEON - Aprimoramento e Inovação no Cuidado e Ensino em Obstetrícia e Neonatologia) ${ }^{(25)}$, which aims to qualify the processes of care, management, training related to childbirth, birth and abortion in hospitals with teaching activities, incorporating a model with practices based on scientific evidence, humanization, safety and guarantee of rights.

It is corroborated that abandonment is in the daily life of maternity hospitals, constituted by the introduction of a range of obstetric interventions, mainly in oxytocite administration, leaving women without the necessary support during the stages of childbirth, but also with the intention of medicalizing their body. So, medicalization can be understood as a form of service management, which ensures that health professionals take ownership of phenomena related to human existence and transform them into objects, subjected to processes of normalization of bodies, their social and sexual practices as well as their pleasures ${ }^{(26-27)}$. As a result, when a woman is subjected to care management, she operationalizes the process of pathologizing childbirth, with intense medicalization, transforming a physiological process into a pathological one at the expense of not exercising scientific evidence in childbirth and birth.

Regarding the support of this conduct on the part of service management, health professionals promote an institutional abandonment of women, setting them "aside" and literally abandoned and deprived of qualified care, supported by care management ${ }^{(28)}$. In fact, when oxytocin is administered, at that time, women are left to feel childbirth ${ }^{(20,27)}$ pains inherent to their sexuality. When women are hospitalized, it seems like an institutional "punishment", because childbirth is so negative that they think about not being subjected to such erroneous acts of their active sexuality ${ }^{(26)}$. It should be stated here that qualified support must be provided, with the introduction of non-pharmacological technologies for pain relief, respecting their citizenship status and the centrality of care, since managers and professionals will be on the spot to promote continuous and qualified care, contrary to what happens: the disrespect of their female condition.

Over the years, the WHO has been a constant movement to build a new paradigm of care for women's health in the pregnancypuerperal cycle ${ }^{(3)}$. In this way, we seek comprehensive obstetric care permeated by quality care based on care practices based on scientific evidence, on women's right to choose and minimization of interventions at this time, aiming at the intersection of science with emotions, ensuring humanized care ${ }^{(29)}$. Ensuring the humanization of childbirth is a right, and the perceptions of the women in the study demonstrate the urgency for the reconfiguration of care processes in relation to the restriction of liquid and solid food during labor, constituting a common routine in hospital care in the studied group. Feeding rejection is supported in preventing the risk of gastric aspiration. However, women in the parturition process need sufficient energy intake to continue with labor ${ }^{(29)}$.

It is known that humanization is a women's human right, based on scientific evidence. In Brazil, the MoH made available the Brazilian National Guidelines for Normal Childbirth Care (Diretrizes Nacionais de Assistência ao Parto Normal) ${ }^{(30)}$. The guidelines reaffirm the right of women to be informed about possible birthing positions and to choose the one they feel most comfortable in giving birth ${ }^{(30)}$. The benefits of humanization translate into a reduction in the duration of the second period of labor, a reduction in instrumentalized and episiotomy births, a reduction in fetal heart rate abnormalities and a reduction in pain ${ }^{(3,20,30)}$.

Verbal violence is evident in the scientific literature ${ }^{(31)}$, which stands out as the second most identified type of violence in the eight health regions of the state of Tocantins, appearing in the form of rude treatment, threats, repression, screams, humiliation and disrespect, as evidenced by the authors ${ }^{(31)}$ and which materializes in verbal violence due to the lack of care, neglect and treatment received by health professionals in obstetric care.

Thus, the production of attitudes that meet the real demands of women, aiming at safety and quality of childbirth care, eliminates obstetric violence, which is supported by care practices and 
scientific evidence protocols that are not recommended by national international health policies ${ }^{(31)}$. Thus, the maintenance of practical childbirth and birth care practices that are not recommended perpetuates institutional obstetric violence, inserted in daily life of maternity hospitals(31-32).

\section{Study limitations}

It is worth highlighting the limitations of this research, since it was developed from a particular reality of the scenarios involved, which did not allow for relationships and their generalization, in addition to the fact that all institutions did not participate in the study, not obtaining the totality of maternity hospitals in the region.

\section{Contributions to nursing}

We know that the strengthening of obstetric care based on scientific evidence and humanization is necessary, as a practice based on technical-scientific knowledge raises a qualified and safe obstetric nursing process for childbirth and birth.

For transformations in the Brazilian obstetric scenario with the transition of the care model, humanization is seen as the foundation for this change, fostered by humanization policies in reproductive health.

This research contributes to the scope for the use of obstetric practices, which are still part of maternity hospitals' daily life so that you can reflect on professional performance based on the humanization of care and scientific evidence.

\section{FINAL CONSIDERATIONS}

The expansion of efforts to change the care model with a focus on humanization implies qualifying health professionals and managers, subsidizing work and management based on science, respect and women's rights for a more qualified and successful childbirth.

The appreciation of this model centralizes the recommendations and guidelines of public policies, such as the Stork Network, which advocates care articulated with the recommendations of international and national organizations, such as the WHO and the MS, for care that is focused on more physiological care, avoiding unnecessary interventions, enabling a new reconfiguration in obstetric care.

With the resignification of a practice by health professionals and managers, the work process becomes qualified, inducing labor and birth as a successful experience. This appreciation allows it to be an inducer of change, inhibiting forms of obstetric violence, which are engendered in the care and management of maternity hospitals, together with women in childbirth.

However, despite these incentives, there is still a lot to advance in obstetric care, which permeates the application of obstetric interventions, sustaining the technocratic model, with women's perception of disrespect, lack of empathy and care in daily life of childbirth and birth, in addition to the use of institutional routines, ensuring professional autonomy and inhibiting women in the birth process scene, prevailing verbal violence in relationships with professionals. Thus, despite the fact that humanization is within an international movement of transformations in care, it is still necessary to break with the challenges to ensure attention focused on a new way of looking at and caring for women, guaranteeing respect, autonomy, empathy and uniqueness of care, supported by public policies in reproductive health.

Thus, it is necessary to expand political incentives for training in maternal and child services in qualification of the management of maternity services and its redefinition in health professionals' daily practice, especially in the Metropolitan Region II of Rio de Janeiro.

\section{SUPPLEMENTARY MATERIAL}

This study is the result of the Final Paper of the Specialization Course in Obstetric Nursing at the Universidade Federal do Rio de Janeiro. The data of the research carried out and defended is available the Final Paper material in its entirety on the link: http:// educapes.capes.gov.br/handle/capes/602798.

\section{FUNDING}

Carlos Chagas Filho Foundation for Research Support of the State of Rio de Janeiro - FAPERJ. Pro-Rectory of Research and Post-Graduate at the Federal University of Pará.

\section{ERRATUM}

Article"Women's perception of labor and birth care: obstacles to humanization", with number of DOI: https://doi.org/10.1590/0034-

7167-2021-0215, published in the journal Revista Brasileira de Enfermagem, 75(Suppl 2): e20210215, in the references:

Where it read:

16. Tong A, Sainsbury P, Craig J. Consolidated criteria for reporting qualitative research (COREQ):a 32-item checklist for interviews and focus groups. Int J Qual Health Care. 2007;19(6):349-57. https://doi.org/10.1093/intqhc/mzm042

17. Fontanella BJB, Luchesi BM, Saidel MGB, Ricas J, Turato ER, Melo DG. Amostragem em pesquisas qualitativas: proposta de procedimentos para constatar saturação teórica. Cad Saúde Pública [Internet]. 2011 [cited 2020 Feb 14];27(2):389-94. Available from: https://periodicos.fiocruz.br/pt-br/publicacao/15050

18. Gil AC. Métodos e técnicas de pesquisa social. 7 ed. São Paulo: Atlas. 2019. 248 p. 
Read:

16. Gil AC. Métodos e técnicas de pesquisa social. 7 ed. São Paulo: Atlas. 2019. 248 p.

17. Tong A, Sainsbury P, Craig J. Consolidated criteria for reporting qualitative research (COREQ):a 32-item checklist for interviews and focus groups. Int J Qual Health Care. 2007;19(6):349-57. https://doi.org/10.1093/intqhc/mzm042

18. Fontanella BJB, Luchesi BM, Saidel MGB, Ricas J, Turato ER, Melo DG. Amostragem em pesquisas qualitativas: proposta de procedimentos para constatar saturação teórica. Cad Saúde Pública [Internet]. 2011 [cited 2020 Feb 14];27(2):389-94. Available from: https://periodicos.fiocruz.br/pt-br/publicacao/15050

\section{REFERENCES}

1. Franchi JVO, Pelloso SM, Ferrari RAP, Cardelli AAM. Access to care during labor and delivery and safety to maternal health. Rev Latino-Am Enfermagem. 2020;28:e3292. https://doi.org/10.1590/1518-8345.3470.3292

2. Mastro ID, Tejada-Llacsa PJ, Reinders S, Pérez R, Solís Y, Alva I, et al. Home birth preference, childbirth, and newborn care practices in rural Peruvian Amazon. PLoS ONE. 2021;16(5):e0250702. https://doi.org/10.1371/journal.pone.0250702

3. World Health Organization (WHO). WHO recommendations Intrapartum care for a positive childbirth experience. Geneva: World Health Organization; 2018. 200p.

4. Carvalho EMP, Amorim FA, Santana LA. Assessment of adherence to best practices in labor and childbirth care by care providers working in public hospitals in the Federal District of Brazil. Ciênc Saúde Coletiva. 2019;24(6):2053-24. https://doi. org/10.1590/1413-81232018246.08502019

5. Palharini LA. Autonomia para quem? o discurso médico hegemônico sobre a violência obstétrica no Brasil. Cad Pagu. $2017 ; 49:$ : 174907. https://doi.org/10.1590/18094449201700490007

6. Luanda P, Minnie CS, Banadé P. Women's experiences of continuous support during childbirth: a meta-synthesis. BMC Pregnancy Childbirth. 2018;18(167):1-11. https://doi.org/10.1186/s12884-018-1755-8

7. Bohren MA, Hofmeyr GJ, Sakala C, Fukuzawa RK, Cuthbert A. Continuous support for women during childbirth. Cochrane Database Syst Rev. 2017;7(7):CD003766. https://doi.org/10.1002/14651858.CD003766.pub6

8. Tajra FS, Pontes RJS, Carvalho FHC. Um possível modelo lógico-avaliativo para a rede cegonha. Sanare [Internet]. 2017 [cited 2020 Feb 14];16(1):80-9. Available from: https://sanare.emnuvens.com.br/sanare/article/view/1098/609

9. Carvalho EMP, Amorim FA, Santana LA. Assessment of adherence to best practices in labor and childbirth care by care providers working in public hospitals in the Federal District of Brazil. Ciênc Saúde Coletiva. 2019;24(6):2053-24. https://doi.org/10.1590/1413-81232018246.08502019

10. Vargens OMC, Alehagen S, Silva ACV. Wanting to give birth naturally: women's perspective on planned homebirth with a nurse midwife. Rev Enferm UERJ. 2021;29:e56113. https://doi.org/10.12957/reuerj.2021.56113

11. Alves MTSSB, Chagas DC, Santos AM, Simões VMF, Ayres BVS, Santos GL, et al. Racial inequality in obstetric good practices and interventions in labor and birth care in Rede Cegonha. Ciênc Saúde Coletiva. 2021;26(3):837-46. https://doi.org/10.1590/1413-81232021263.38982020

12. Costa LD, Warmling KM, Cero TD, Dalorsoletta K, Zonta FNS, Trevisan MG, et al. Adherence of professionals to good obstetric practices and interventions performed with parturientes. Rev Rene. 2021;22:e61474. https://doi.org/10.15253/2175-6783.20212261474

13. Gama SGN, Viellas EF, Medina ET, Angulo-Tuesta A, Silva CKRTS, Silva SD, et al. Delivery care by obstetric nurses in maternity hospitals linked to the Rede Cegonha, Brazil - 2017. Ciênc Saúde Coletiva. 2021;26(3):919-29. https://doi.org/10.1590/1413-81232021263.28482020

14. Amaral RCS, Alves VH, Pereira AV, Rodrigues DP, Silva LA, Marchiori GRS.The insertion of the nurse midwife in delivery and birth: obstacles in a teaching hospital in the Rio de Janeiro state. Esc Anna Nery. 2019;23(1):e20180218. https://doi.org/10.1590/2177-9465-ean-2018-0218

15. Oliveira VJ, Penna CMM. Discussing obstetric violence through the voices of women and health professionals. Texto Contexto Enferm. 2017;26(2):e06500015. https://doi.org/10.1590/0104-07072017006500015

16. Gil AC. Métodos e técnicas de pesquisa social. $7^{\circ}$ ed. São Paulo: Atlas. 2019. 248 p

17. Tong A, Sainsbury P, Craig J. Consolidated criteria for reporting qualitative research (COREQ):a 32-item checklist for interviews and focus groups. Int J Qual Health Care. 2007;19(6):349-57. https://doi.org/10.1093/intqhc/mzm042

18. Fontanella BJB, Luchesi BM, Saidel MGB, Ricas J, Turato ER, Melo DG. Amostragem em pesquisas qualitativas: proposta de procedimentos para constatar saturação teórica. Cad Saúde Pública [Internet]. 2011 [cited 2020 Feb 14];27(2):389-94. Available from: https://periodicos. fiocruz.br/pt-br/publicacao/15050

19. Bardin L. Análise de conteúdo. Lisboa: Edições 70. 2011. 280 p. 
20. Ministério da Saúde (BR). Diretrizes nacionais de assistência ao parto normal. Brasília: Ministério da Saúde; 2017. 51p.

21. Côrtes CT, Oliveira SMJV, Santos RCS, Francisco AA, Riesco MLG, Schimoda GT. Implementation of evidence-based practices in normal delivery care. Rev Latino-Am Enfermagem. 2018;26:e2988. https://doi.org/10.1590/1518-8345.2177.2988

22. Joang H, Qian X, Carroli G, Garner P. Selective versus routine use of episiotomy for vaginal birth. Cochrane Database Syst Rev. 2017;2:CD000081. https://doi.org/10.1002/14651858.CD000081.pub3

23. Gurol-Urganci I, Bidwell P, Sevdalis N, Silverton L, Novis V, Freeman R, et al. Impact of a quality improvement project to reduce the rate of obstetric anal sphincter injury: a multicentre study with a stepped-wedge design. BJOG. 2021;128(3):584-92. https://doi.org/10.1111/1471-0528.16396

24. Pierce-Williams RAM, Saccone G, Berghella V. Hands-on versus hands-off techniques for the prevention of perineal trauma during vaginal delivery: a systematic review and meta-analysis of randomized controlled trials. J Matern Fetal Neonatal Med. 2021;34(6):993-1001. https:// doi.org/10.1080/14767058.2019.1619686

25. Ministério da Saúde (BR). Apiceon - Aprimoramento e Inovação no Cuidado e Ensino em Obstetrícia e Neonatologia. Brasília: Ministério da Saúde; 2017.31p.

26. Ferrazza D, Peres WS. Medicalização do corpo da mulher e criminalização do aborto no Brasil. Fractal, Rev Psicol. 2016;28(1):17-25. https:// doi.org/10.1590/1984-0292/1016

27. Sala VVV. La enfermedad normal": aspectos históricos y políticos de la medicalización del parto. Sex Salud Soc. 2021;34:90-107. https://doi. org/10.1590/1984-6487.sess.2020.34.06.a

28. Nucci M, Nakano AR, Teixeira LA. Synthetic oxytocin and hastening labor: reflections on the synthesis and early use of oxytocin in Brazilian obstetrics. Hist Cienc Saude-Manguinhos. 2018;25(4):979-98. https://doi.org/10.1590/S0104-59702018000500006

29. Pinto LMTR, Trezza MCSF, Santos AAP, Melo GC, Silva JMO, Oliveira LLF. Manejo alimentar durante o parto sob a percepção da mulher. Rev Enferm UERJ [Internet] 2017 [cited 2020 Feb 14];25:e14205. Available from: http://www.e-publicacoes.uerj.br/index.php/enfermagemuerj/ article/view/14205/25492

30. Sousa JL, Silva IP, Gonçalves LRR, Nery IS, Gomes IS, Sousa LFC. Perception of puerperas on the vertical position in childbirth. Rev Baiana Enferm. 2018;32:e27499. https://doi.org/10.18471/rbe.v32.27499

31. Guimarães LBE, Jonas E, Amaral LROG. Obstetric violence in public maternity wards of the state of Tocantins. Rev Estud Fem. 2019;26(1):e43278. https://doi.org/10.1590/1806-9584.2018v26n143278

32. Marrero L, Bruggemann OM. Institutional violence during the parturition process in Brazil: integrative review. Rev Bras Enferm. 2018;71(3):1219-28. https://doi.org/10.1590/0034-7167-2017-0238 